\title{
PENGARUH WARNA CAHAYA LIGHT-EMITTING DIODES (LED) INTENSITAS RENDAH DAN CEKAMAN DINGIN TERHADAP PERTUMBUHAN VEGETATIF ANGGREK Phalaenopsis HIBRIDA
}

\author{
Dzikrina Nurunisa $^{1^{*}}$, Aries Bagus Sasongko ${ }^{2}$, Ari Indrianto ${ }^{3}$ \\ ${ }^{1,2,3}$ Fakultas Biologi, Universitas Gadjah Mada, Sekip Utara, Yogyakarta \\ *E-mail:dzikrinana9696@yahoo.com
}

\begin{abstract}
Red and blue light are the main lights absorbed by plants and play important roles in photosynthesis, growth and development of hybrid Phalaenopsis orchid plants. Cold stress can trigger the formation of generative organs and slow down the growth of vegetative organs. However, the effect of low light intensity and cold stress on vegetative and generative growth of Phalaenopsis orchids was not yet known. This study was aimed to determine the effect of low-intensity light colors and cold temperature stress on the vegetative growth of hybrid Phalaenopsis orchids. The \pm 2 -year-old orchids were grown in a growth chamber with irradiation of white LED lights as controls (100 lx), red, blue, and red + blue (30 lx each) for treatment. The water temperature treatments were divided into cold stress $\left(4.5^{\circ} \mathrm{C}\right)$, room temperature $\left(28^{\circ} \mathrm{C}\right)$ and negative control (without watering). The length of leaves, number of leaves, and stomatal density were measured for 60 days. The results showed that low intensity LED light can increase the length of the leaves, but red light gives the highest leaf length increase. Blue LED light treatment provided the highest stomata density against other light colors. On the other hand, cold stress inhibited leaf growth. Based on ANOVA and Duncan Test, it was found that between each treatment, both in light colors and water temperatures, the results were not signifficantly different. The light colors and water temperatures had no effect on the number of leaves or the opening of stomata.
\end{abstract}

Keywords: LED; Light; Orchid; Stress; Temperature.

\section{PENDAHULUAN}

Anggrek (famili Orchidaceae) adalah kelompok tumbuhan dengan jumlah anggota terbesar diseluruh dunia, dengan setidaknya setengah dari anggotanya merupakan tanaman Crassulean Acid Metabolism (CAM) (Winter \& Smith, 1996),yaitu tanaman yang melakukan fiksasi $\mathrm{CO}_{2}$ di malam hari dan asimilasi untuk pembentukan senyawa organik di siang hari. Sebagai tanaman CAM, anggrek memiliki karakteristik pertumbuhan yang lama, disebabkan oleh produktivitas fotosintesisnya yang rendah dibandingkan tanaman C3 (Lüttge, 2001). Anggrek Phalaenopsis adalah anggrek yang paling banyak diperdagangkan yakni lebih dari $75 \%$ dari semua jenis anggrek (Griesbach, 2002), Anggrek ini digemari terutama karena memiliki bentuk, ukuran dan warna yang beragam serta memiliki harga jual yang relatif tinggi dan stabil (Kencana, 2007). Selain itu, genus anggrek ini sudah banyak dikembangkan hibridanya sehingga variasi bunganya semakin beragam. Diperlukannya pengetahuan mengenai faktor yang berpengaruh beserta peranannya terhadap pertumbuhan vegetatif dan generatif anggrek Phalaenopsis Hibrida, sehingga dapat dilakukan modifikasi budidaya yang mampu memicu pertumbuhan anggrek ini.

Cahaya merah dan biru merupakan cahaya utama yang dibutuhkan dalam pertumbuhan dan perkembangan tanaman, hal tersebut dikarenakan kedua cahaya tersebut merupakan sumber energi utama untuk asimilasi $\mathrm{CO}_{2}$ dalam fotosintesis. Cahaya merah memiliki gelombang cahaya yang paling efisien untuk fotosintesis (Runkle, 2015), sedangkan cahaya biru sangat diperlukan untuk memicu pertumbuhan tanaman yang sehat (Okamoto et al., 1996) dan memicu pembungaan (Runkle, 2015).

Cekaman dingin (cold stress) adalah istilah untuk menyebut suatu pemberian perlakuan stres pada tanaman berupa suhu yang jauh lebih dingin dari suhu metabolisme normalnya agar tanaman merasa tercekam, yang tujuan akhirnya adalah memicu pembungaan pada tanaman tersebut. Laju perkembangan organ vegetatif pada tanaman akan meningkat seiring dengan peningkatan suhu kearah 
suhu optimumnya (Hatfield \& Prueger, 2015), yang artinya semakin rendah suhu diberikan maka tanaman akan makin merasa tercekam, sehingga terjadi pensinyalan pembungaan untuk meneruskan kehidupannya pada keturunannya. Cekaman berupa temperatur, misalnya pemberian suhu yang dingin (cold stress) dapat dilakukan untuk memicu pembungaan, misalnya pada anggrek Dendrobium nobile (Ichihasi, 1997), dan Phalaenopsis (Blanchard \& Runkle, 2006).

Pada penelitian ini akan diamati pengaruh perlakuan warna cahaya LED dan cekaman dingin terhadap pertumbuhan vegetatif anggrek Phalaenopsis hibrida. Pertumbuhan vegetatif dapat dilihat dari aktivitas stomata karena berhubungan dengan transpirasi dan fotosintesis, maupun dari pertambahan panjang dan jumlah daun.

\section{METODOLOGI PENELITIAN}

\section{Alat Dan Bahan}

Tanaman yang digunakan adalah Phalaenopsis Hibrida berusia \pm 2 tahun sejak aklimatisasi dari kondisi in vitro. Untuk perlakuan cekaman dingin, diperlukan air dingin bersuhu \pm $4,5^{\circ} \mathrm{C}$ dan air biasa bersuhu $\pm 28,5^{\circ} \mathrm{C}$ dengan volume $12 \mathrm{~mL}$ disetiap penyiraman. Untuk pengamatan stomata, bahan yang digunakan adalah lem super rekat Alteco dan selotip.

Alat yang digunakan dalam penelitian ini yakni 4 buah growth chamber sederhana yang terbuat dari kerangka kawat besi dan penutup berupa kain hitam, rangkaian lampu LED (merah, biru, merah + biru dan putih sebagai kontrol) dengan spesifikasi 12 Watt dengan intensitas rendah yang dipasangkan pada tiap-tiap growth chamber, timer, penggaris, gelas benda, mikroskop, dan aplikasi OptiLab.

\section{Teknik Pengumpulan Data}

Anggrek Phalaenopsis Hibrida dikelompokkan dalam 4 growth chamber yang disinari LED putih (kontrol), merah, biru, dan merah + biru (perlakuan) dengan periode 8 jam siang: 16 jam malam selama 60 hari. Tiap growth chamber dikelompokkan lagi menjadi 3 untuk perlakuan suhu dingin, suhu ruang, dan kontrol negatif (tanpa penyiraman). Setiap 10 hari dilakukan pengamatan pertambahan panjang daun dan jumlah daun pada daun termuda pertama, kedua dan ketiga (daun A, daun B dan daun C). Di awal dan akhir penelitian dibuat preparat stomata sederhana dengan lem Alteco, selotip dan gelas penutup untuk dihitung jumlah stomata dan perilaku stomata sebelum dan sesudah setiap perlakuan.

Analisis data dilakukan dengan perangkat statistik SPSS (versi 17). Data diolah menggunakan analisis variansi (ANOVA) dan Uji Duncan untuk membandingkan pengaruh warna cahaya LED dan pemberian cekaman dingin terhadap pertambahan panjang daun dan densitas stomata anggrek Phalaenopsis Hibrida.

\section{HASIL DAN PEMBAHASAN}

\section{A. Hasil}

\section{Pertambahan panjang daun dengan pengaruh warna cahaya dan suhu air}

Pertambahan panjang daun dengan pengaruh warna cahaya ditampilkan pada Gambar 1 . Pertambahan panjang daun terjadi pada setiap jenis perlakuan warna cahaya LED di setiap 10 hari pengamatan. Pada grafik terlihat bahwa pertambahan panjang daun terbesar terjadi pada daun paling muda (daun A). Pada daun A, pemberian cahaya merah menghasilkan pertambahan panjang daun yang lebih besar dibandingkan perlakuan lainnya, yakni sebesar 0,74 $\pm 0,27 \mathrm{~cm}$. Sementara, pemberian cahaya biru menghasilkan pertambahan panjang daun yang paling rendah yaitu sebesar $0,2 \pm 0,11 \mathrm{~cm}$. Pertambahan panjang daun $\mathrm{B}$ dan daun $\mathrm{C}$ sangat kecil dan tidak terlihat pengaruh yang konsisten dari tiap perlakuan warna cahaya.

Pertambahan panjang daun dengan pengaruh cekaman dingin melalui suhu air ditampilkan pada Gambar 2. Seperti pada perlakuan warna cahaya, pada tiap perlakuan terjadi pertambahan panjang daun di setiap 10 hari pengamatan, dan lebih terlihat pada daun A. Pada hari ke-10 hingga hari ke-40, perlakuan dengan suhu dingin mengalami pertumbuhan daun A yang sedikit lebih besar daripada perlakuan suhu biasa. Namun pada hari ke-50 hingga hari ke-60, pertambahan panjang daun terbesar terjadi pada perlakuan suhu biasa (suhu ruang), yaitu sebesar $0,59 \pm 0,18 \mathrm{~cm}$. Kontrol negatif (tanpa pemberian air) memberikan pertambahan panjang daun yang paling kecil dibandingkan kedua perlakuan. Pertambahan panjang daun $\mathrm{B}$ dan daun $\mathrm{C}$ sangat kecil dan tidak terlihat pengaruh yang konsisten dari tiap perlakuan warna cahaya. Berdasarkan analisis ANOVA dan DMRT, pertambahan panjang daun pada perlakuan warna cahaya maupun suhu air tidak berbeda nyata. 


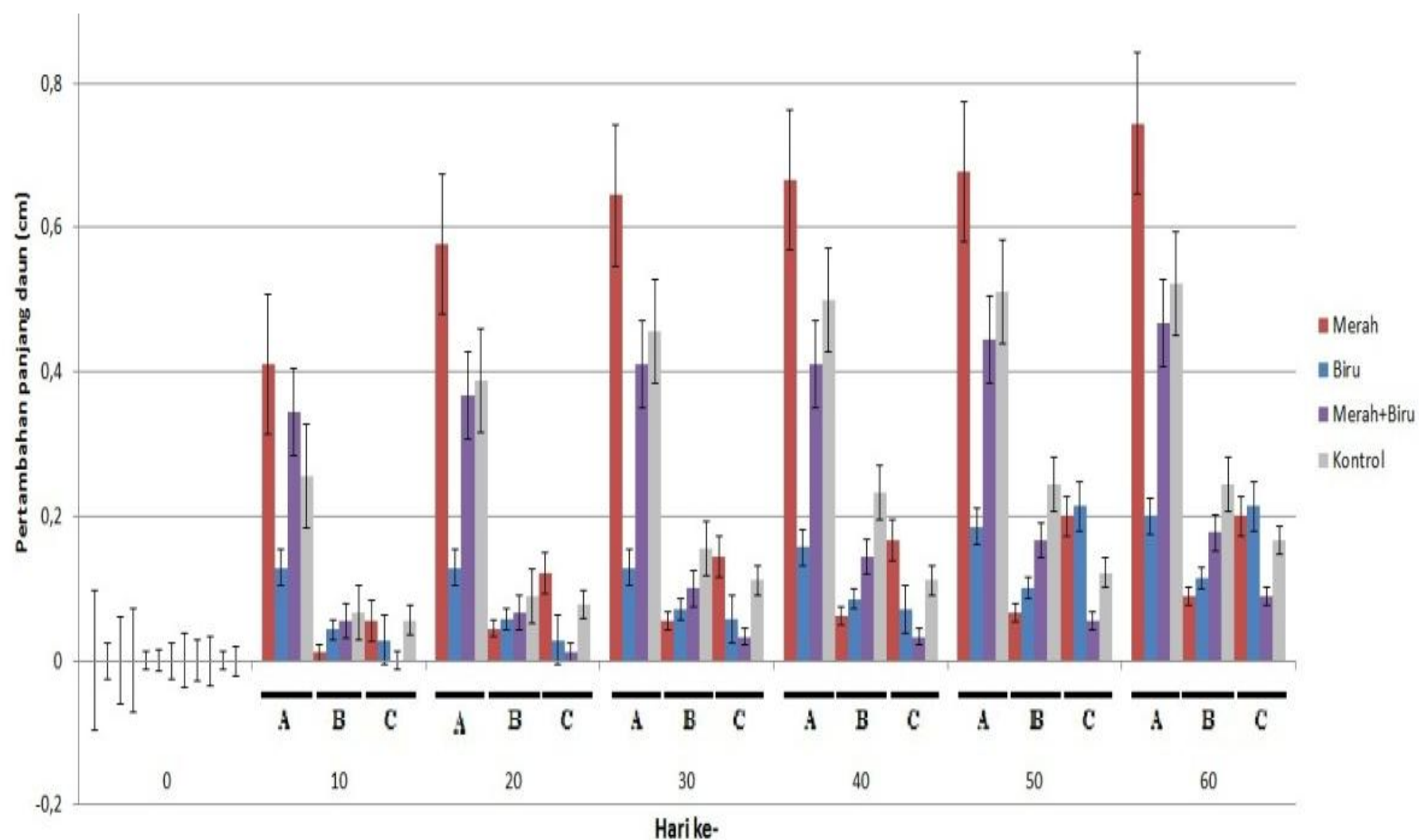

Gambar 1. Pengaruh warna cahaya lampu LED terhadap rerata pertambahan panjang daun. A, B, dan $C$ berturut-turut menunjukkan rerata pertambahan panjang daun $A$, daun $B$, dan daun $C$

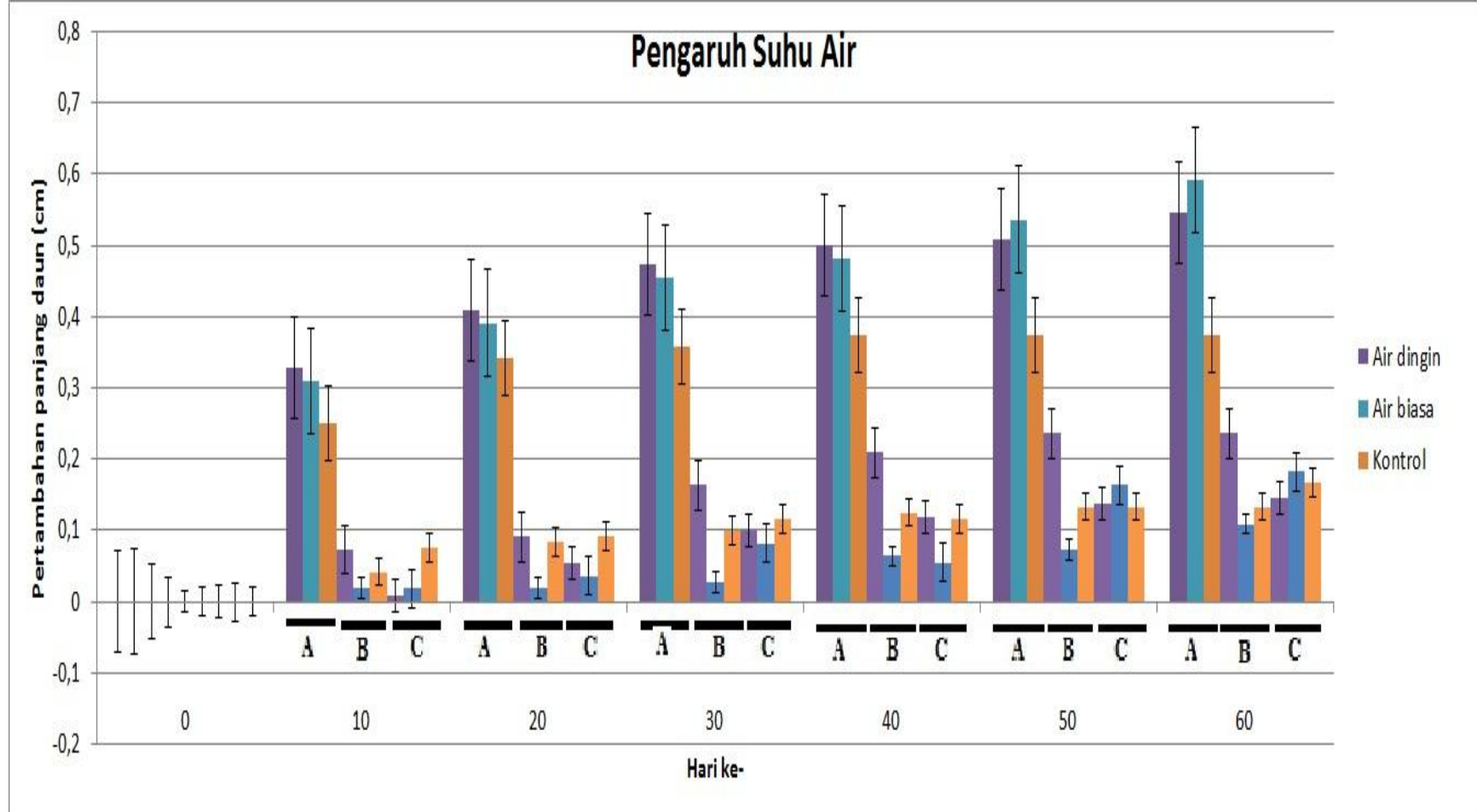

Gambar 2. Pengaruh cekaman dingin melalui suhu air terhadap rerata pertambahan panjang daun. A, $B$, dan $C$ berturut-turut menunjukkan rerata pertambahan panjang daun $A$, daun $B$, dan daun $C$ 
Jumlah daun dengan pengaruh warna cahaya dan suhu air

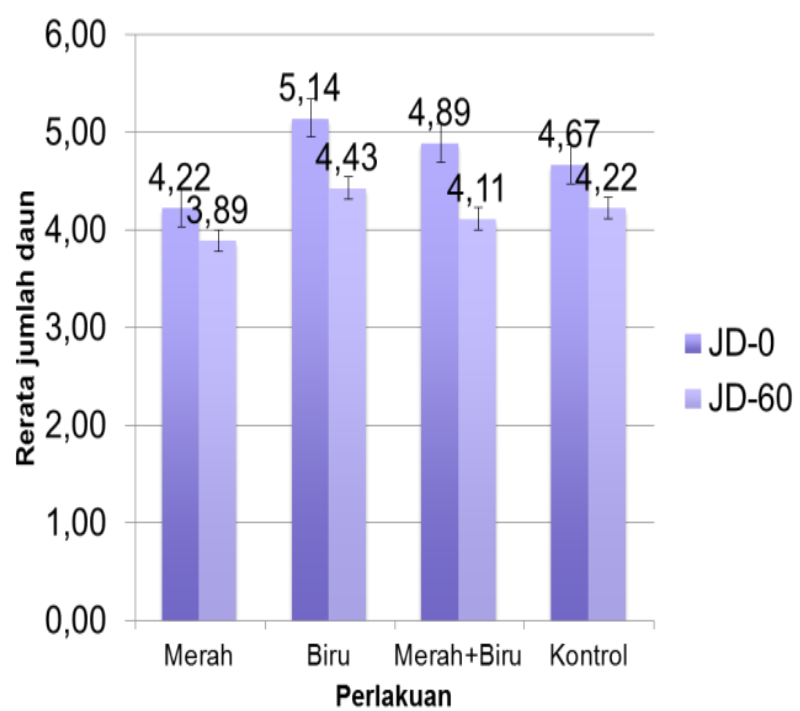

(a)

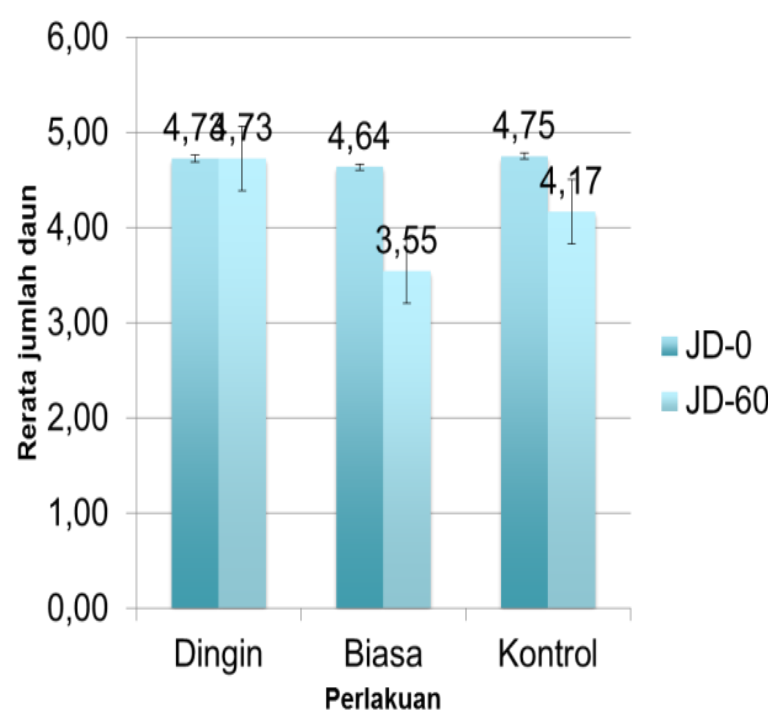

(b)

Gambar 3. Rerata jumlah daun sebelum dan sesudah perlakuan dengan

(a) Pengaruh warna cahaya LED dan (b) Pengaruh suhu air. JD-0: Jumlah daun sebelum perlakuan; JD-60: Jumlah daun setelah 60 hari perlakuan.

Perubahan rerata jumlah daun dengan pengaruh warna cahaya LED ditunjukkan pada Gambar 3a. Terlihat bahwa rerata jumlah daun untuk setiap perlakuan setelah hari ke-60 mengalami penurunan dibandingkan rerata jumlah daun awal, yang disebabkan oleh kematian dan kerontokan daun. Rerata jumlah daun yang rontok pada perlakuan cahaya merah paling sedikit dibandingkan perlakuan warna lainnya, yaitu dari 4,22 $\pm 0,13$ daun menjadi 3,89 $\pm 0,3$ daun.

Perubahan rerata jumlah daun dengan pengaruh cekaman dingin melalui suhu air ditunjukkan pada Gambar 3b.Terkecuali perlakuan suhu dingin, rerata jumlah daun untuk setiap perlakuan setelah hari ke-60 mengalami penurunan dibandingkan rerata jumlah daun awal yang disebabkan oleh kerontokan daun.

\section{Densitas stomata dengan perlakuan warna cahaya dan suhu air}

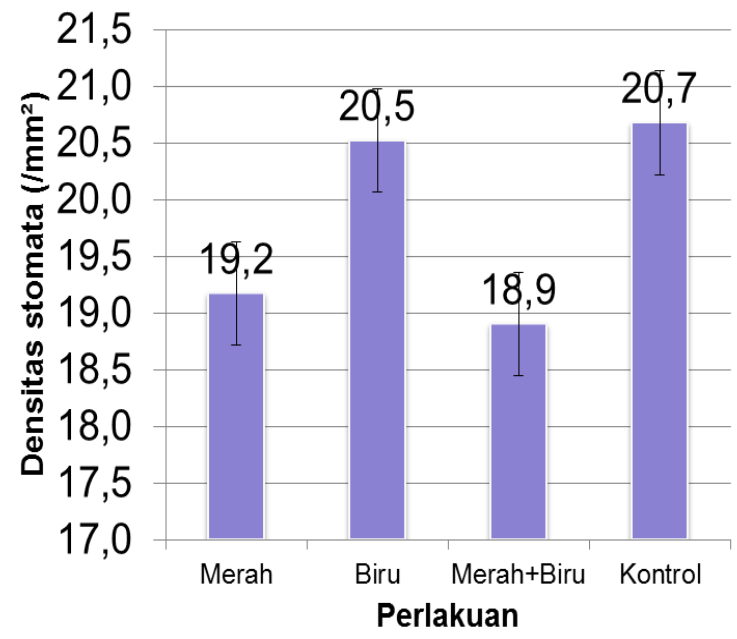

(a)

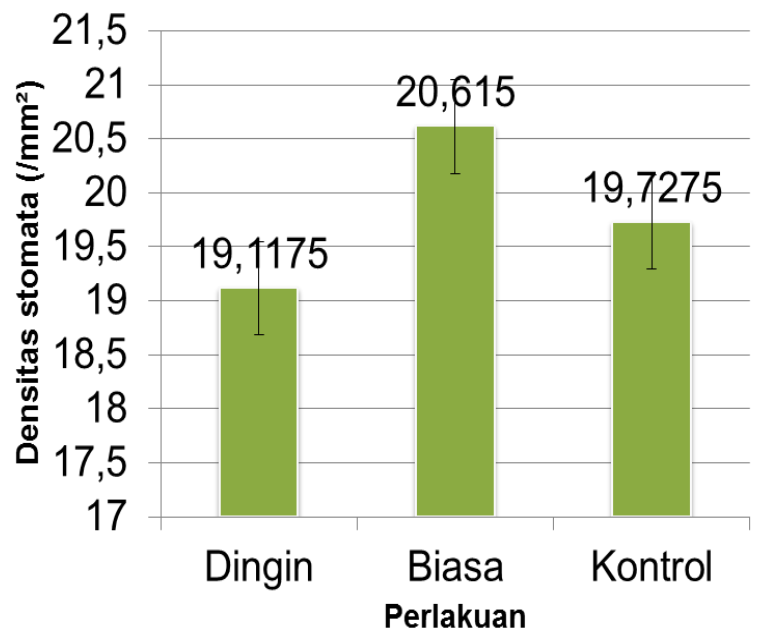

(b)

Gambar 4. Rerata densitas stomata dengan a) Pengaruh warna cahaya LED dan b) Pengaruh suhu air.

Data mengenai densitas stomata setelah 60 hari perlakuan dengan warna cahaya berbeda ditunjukkan pada Gambar 4a. Densitas stomata terbesar ditunjukkan oleh perlakuan cahaya biru, yaitu sebesar $20,5 \pm 0,26$ stomata/mm $\mathrm{mm}^{2}$ yang hampir mendekati densitas stomata pada kontrol $(20,7 \pm$ 
1,00 stomata $/ \mathrm{mm}^{2}$ ). Sedangkan densitas stomata terkecil ditunjukkan oleh perlakuan cahaya merah dan biru, yaitu sebesar 18,9 $\pm 0,68$ stomata $/ \mathrm{mm}^{2}$. Antar perlakuan tidak berbeda nyata berdasarkan analisis ANOVA dan DMRT.

Pengaruh cekaman dingin melalui suhu air terhadap densitas stomata ditunjkkan pada Gambar 4b. Densitas stomata terbesar terdapat pada perlakuan suhu air biasa (20,6 $\pm 0,38$ stomata $/ \mathrm{mm}^{2}$ ), sementara densitas stomata terkecil terdapat pada perlakuan suhu dingin $(19,1 \pm 0,8$ stomata $/ \mathrm{mm}^{2}$ ). Antar perlakuan tidak berbeda nyata berdasarkan analisis ANOVA dan DMRT.

\section{Pembukaan stomata dengan perlakuan warna cahaya dan suhu air}

Pembukaan stomata diukur pada pukul 09.30, 12.30, 15.30 dan 17.45. Kategori pembukaan stomata ditunjukkan pada gambar Gambar 5. Pembukaan stomata untuk tiap perlakuan dirangkum dalam Tabel 1. Kategori pembukaan yang ditemukan pada setiap sampel adalah menutup $(-)$, membuka sedikit $(+)$, dan membuka lebar $(++)$. Sebagian besar stomata yang diamati mengalami pembukaan sedikit $(++)$. Tidak terdapat perbedaan yang mencolok antara tiap perlakuan dan kontrol.

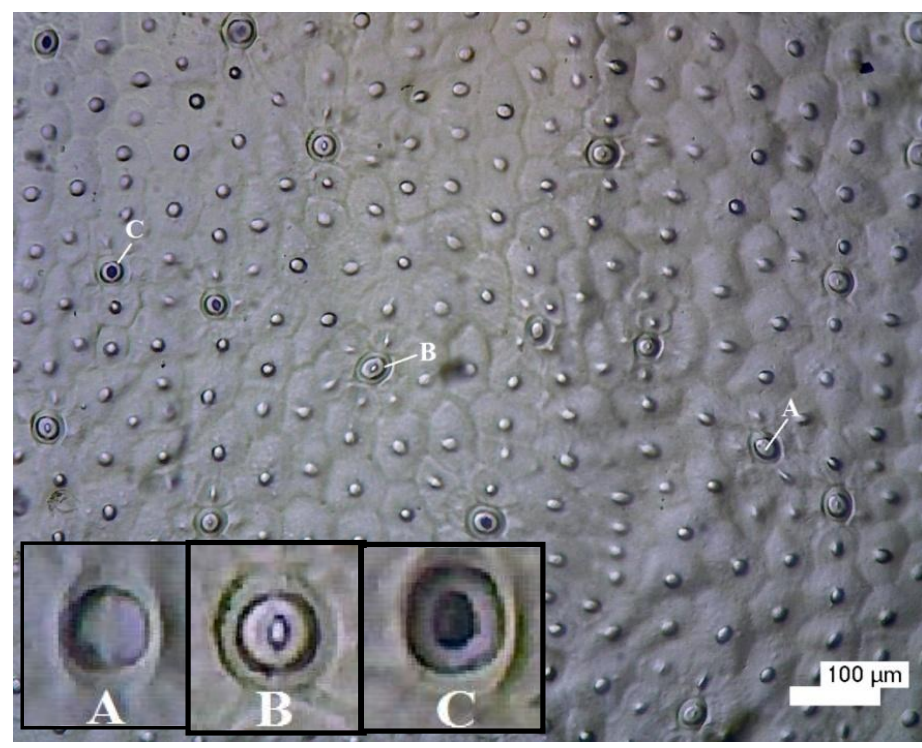

Gambar 5 Kategori pembukaan stomata pada daun anggrek Phalaenopsis hibrida.

A: stomata menutup (-); B: stomata sedikit membuka (+); C: stomata terbuka lebar (++)

Tabel 1. Pembukaan stomata pada setiap kelompok perlakuan

\begin{tabular}{llcccc}
\hline \multicolumn{1}{c}{ Warna } & \multicolumn{1}{c}{ Suhu } & $\mathbf{0 9 . 3 0}$ & $\mathbf{1 2 . 3 0}$ & $\mathbf{1 5 . 3 0}$ & $\mathbf{1 7 . 4 5}$ \\
\hline Merah & Dingin & + & + & + & + \\
& Biasa & + & + & + & + \\
\multirow{5}{*}{ Biru } & Kontrol & + & + & + & + \\
& Dingin & - & + & + & + \\
\multirow{5}{*}{ Merah + Biru } & Biasa & + & + & + & + \\
& Kontrol & + & + & + & + \\
& Dingin & - & + & + & + \\
& Biasa & + & + & + & + \\
& Kontrol & + & + & + & + \\
& Dingin & + & + & + & + \\
\hline
\end{tabular}

\begin{tabular}{cl}
\hline Keterangan: \\
- & $:$ sebagian besar stomata menutup \\
+ & $:$ sebagian besar stomata sedikit membuka \\
++ & $:$ sebagian besar stomata membuka lebar
\end{tabular}

\section{B. Pembahasan}

Penelitian ini bertujuan untuk melihat perbedaan pertambahan panjang daun, jumlah daun, densitas stomata serta pembukaan stomata anggrek Phalaenopsis hibrida yang telah dipaparkan warna cahaya berbeda serta disiram dengan air dingin untuk mengindikasikan cekaman temperatur dingin. Pemberian warna cahaya berbeda dilakukan untuk mengetahui peranan gelombang cahaya tertentu terhadap pertumbuhan vegetatif Phalaenopsis 
hibrida. Lampu yang digunakan berjenis LightEmitting Diodes (LED) karena memiliki sejumlah keuntungan, yakni memiliki spektrum yang sempit sehingga bisa menghasilkan panjang gelombang tertentu serta tidak menghasilkan radiasi panas sehingga memungkinkan penyerapan cahaya yang maksimum tanpa membahayakan tanaman (Landis et al., 2013). Penggunaan lampu LED dengan intensitas rendah ditujukan untuk mensimulasikan keadaan dibawah kanopi maupun kondisi indoor, karena anggrek Phalaenopsis merupakan anggrek dengan toleransi intensitas cahaya rendah yang di alam tumbuh dibawah kanopi serta sering digunakan sebagai tanaman hias dalam ruangan. Pemberian cekaman dingin berfungsi untuk membuktikan terjadinya respon cekaman oleh tanaman yang ditandai dengan terhambatnya laju fotosintesis dan pertumbuhan vegetatif yang dilanjutkan dengan terstimulasinya perkembangan generatif. Usia anggrek yang dipilih adalah \pm 2 tahun atau memasuki usia siap untuk berbunga, karena dianggap pada usia tersebut anggrek lebih responsif terhadap cekaman dingin.

Dalam pengamatan pertambahan panjang daun, digunakan tiga daun teratas yang dinamakan daun $\mathrm{A}$, daun $\mathrm{B}$ dan daun $\mathrm{C}$. Hal tersebut dilakukan untuk menyeragamkan jumlah daun yang diukur panjangnya, serta karena tiga daun teratas adalah daun termuda yang lebih aktif membelah dibandingkan daun tua, sehingga pertambahan panjang daun tampak lebih terlihat.

Berdasarkan hasil pengamatan, didapatkan bahwa pertumbuhan daun paling jelas terlihat pada daun termuda (daun $\mathrm{A}$ ), sedangkan daun $\mathrm{B}$ dan daun $\mathrm{C}$ yang lebih tua menunjukkan pertambahan panjang daun yang sangat sedikit. Hal ini menandakan bahwa selama kurun penelitian, daun A masih dalam tahap pertumbuhan dan belum mencapai panjang daun maksimum, oleh karena itu pertumbuhannya lebih jelas terlihat. Sementara daun $\mathrm{B}$ dan daun $\mathrm{C}$ kemungkinan sudah mendekati panjang daun maksimum sehingga pertambahan panjang daun yang teramati sangat kecil. Selain itu, daun A adalah daun termuda yang posisinya paling atas dan paling dekat dengan sumber cahaya lampu LED, dengan begitu lebih banyak cahaya yang terserap untuk pertumbuhan daun termuda. Sementara daun-daun yang lebih tua lebih tertutup oleh daun diatasnya sehingga hanya sedikit cahaya yang terserap oleh daun.

Pada daun A, didapatkan bahwa cahaya lampu LED warna merah menghasilkan pertambahan panjang daun yang lebih besar dibandingkan kontrol dan perlakuan warna lain. Dengan ini bisa diperkirakan cahaya dengan panjang gelombang merah lebih baik dalam menginduksi pemanjangan daun daripada warna cahaya lain. Hal ini sesuai dengan pernyataan Runkle (2016) bahwa penyinaran dalam ruangan dengan cahaya merah saja dapat menyebabkan pemanjangan daun, yang apabila tidak diseimbangkan dengan warna cahaya lain maka dapat menghasilkan daun yang panjang namun kurang sehat. Sementara itu, cahaya LED warna biru menghasilkan pertambahan panjang daun yang paling kecil bahkan di daun termudanya. Hal tersebut mungkin disebabkan oleh peranan cahaya biru terhadap tanaman yang memang sebagai penghambat pemanjangan organ tanaman. Cahaya biru bertindak sebagai penyeimbang cahaya merah sehingga pemanjangan daun tidak berlebihan, sehingga disarankan setiap lampu LED yang digunakan untuk menumbuhkan tanaman mengandung paling tidak $10-20 \%$ cahaya biru (Runkle, 2015). Pernyataan ini juga ditunjukkan pada hasil penelitian ini, yakni pertambahan panjang daun A dengan perlakuan cahaya merah dan biru lebih besar dibandingkan cahaya biru saja dan lebih kecil dibandingkan cahaya merah saja.

Hal pertama yang ditunjukkan pada perlakuan suhu air yaitu bahwa pemberian air yang sering, baik bersuhu dingin maupun bersuhu biasa berdampak pada pertumbuhan organ daun yang lebih cepat dibandingkan kontrol negatif yang 'tidak disiram' (disiram hanya sekali seminggu untuk tetap hidup). Artinya, anggrek yang mendapat banyak air, selama masih dalam kisaran toleransinya, akan lebih cepat tumbuh daripada yang sangat jarang diberi air. Kemudian, hal lain yang bisa diamati adalah adanya perbedaan pertambahan panjang daun antara perlakuan dengan suhu air dingin dan dengan suhu air biasa, meski perbedaannya sangat kecil. Perlakuan suhu air biasa menghasilkan pemanjangan daun sedikit lebih besar dibandingkan perlakuan suhu dingin. Menurut Hatfield \& Prueger (2015), laju perkembangan organ vegetatif pada tanaman meningkat seiring dengan peningkatan suhu kearah suhu optimumnya, yang artinya semakin rendah suhu diberikan maka pertumbuhan dan perkembangan vegetatif juga akan berkurang sebagai respons cekaman. Apabila tanaman mengalami cekaman, tanaman akan meresponsnya sebagai persinyalan pembungaan untuk meneruskan kehidupannya pada keturunannya. Diduga respon cekaman yang terjadi pada tanaman anggrek berupa pertambahan panjang daun yang lebih cepat namun terhenti di angka yang lebih kecil dibandingkan dengan perlakuan suhu biasa. 
Rerata jumlah daun anggrek, baik dengan perlakuan warna cahaya maupun cekaman dingin berkurang dibandingkan rerata jumlah daun di hari pertama. Hal ini berlawanan dengan dugaan awal bahwa selama penelitian jumlah daun akan bertambah. Berkurangnya jumlah daun disebabkan oleh daun yang menguning, kemudian lama kelamaan layu dan rontok. Dedaunan yang rontok semuanya merupakan daun tua yang terletak dibagian bawah tanaman. Berkurangnya rerata jumlah daun untuk setiap perlakuan mungkin disebabkan oleh deprivasi atau kekurangan intensitas cahaya, karena pada penelitian ini intensitas cahaya yang diberikan jauh lebih kecil dibandingkan dengan intensitas cahaya di tempat asal sampel tanaman. Selain itu, batang Phalaenopsis yang monopodial membuat daun yang lebih muda berada diatas daun yang lebih tua, menyebabkan daun yang lebih tua tertutup dan kurang terpapar cahaya, sehingga tidak terjadi fotosintesis dan lama kelamaan daun mati. Hal ini juga menunjukkan bahwa paparan cahaya pada daun memang penting agar daun dapat tetap menjalankan metabolismenya dan tumbuh.

Selanjutnya adalah pengamatan stomata. Stomata yang diamati adalah stomata yang terdapat pada sisi bagian bawah (sisi abaksial) daun anggrek, karena stomata anggrek paling banyak ditemukan di sisi abaksial daun. Berdasarkan hasil pengamatan, didapatkan bahwa densitas stomata anggrek yang diberi perlakuan cahaya biru paling besar dibandingkan perlakuan lain, dan hampir mendekati kontrol. Hal ini menandakan bahwa dengan cahaya dengan panjang gelombang biru saja, densitas stomata mampu menyamai densitas stomata kontrol. Penelitian oleh Muneer et al. (2014) juga menunjukkan bahwa densitas stomata tanaman kobis yang disinari cahaya biru lebih besar dibandingkan dengan perlakuan cahaya lain yaitu cahaya merah dan hijau, diikuti dengan laju fotosintesis tanaman juga lebih tinggi dengan paparan cahaya biru. Bila dikaitkan dengan fungsinya, cahaya biru memang warna yang penting untuk fotosintesis dan menghasilkan tanaman yang sehat (Okamoto et al., 1996). Dari penelitian ini, bisa diduga bahwa cahaya biru dapat menyebabkan penambahan jumlah stomata untuk memaksimalkan laju fotosintesisnya dan menjaga kondisi tanaman tetap sehat.

Sementara itu, cekaman dingin ternyata menyebabkan densitas stomata lebih sedikit dibandingkan anggrek yang disiram dengan air bersuhu normal (suhu ruang). Penyebab yang memungkinkan adalah terjadi cukup stress pada jaringan daun yang mampu menghambat pembentukan stomata-stomata baru dibandingkan dengan air bersuhu normal.

Bila dilihat dari peranannya, seharusnya penyinaran dengan cahaya merah dan cahaya biru secara bersamaan mampu memberikan dampak positif yang didapat dari masing-masing warna cahaya. Namun, pada penelitian ini, perlakuan dengan cahaya merah dan biru justru menghasilkan pertambahan panjang daun yang kecil dan densitas stomata yang kecil pula. Hal ini kemungkinan berkaitan erat dengan kombinasi porsi cahaya yang tidak optimum. Menurut Runkle (2015), sebuah lampu LED yang bagus bagi tanaman harus setidaknya mengandung $75-90 \%$ cahaya merah dan $10-20 \%$ cahaya biru. Dengan begitu, dalam merangkai lampu gabungan merah dan biru seharusnya cahaya merah lebih banyak sedangkan cahaya biru hanya diperlukan dalam jumlah sedikit. Sementara pada penelitian ini, perbandingan cahaya merah dan biru sebesar 1:1 atau masing-masing $50 \%$.

Pembukaan stomata diamati pada pukul 09.30 (pagi hari), 12.30 (siang hari), 15.30 (sore hari) dan 17.45 (malam hari). Pemilihan jam-jam tersebut dilakukan agar dapat diketahui jadwal pembukaan stomata pada anggrek Phalaenopsis dan pengaruh perlakuan terhadap jadwal pembukaan tersebut. Pukul 09.30 merepresentasikan pagi hari saat lampu LED pertama menyala, sementara pukul 17.45 merepresentasikan malam hari setelah lampu LED padam. Pada penelitian ini, tidak terlihat pola pembukaan dan penutupan yang teratur, melainkan kebanyakan stomata yang teramati berada pada kondisi 'sedikit membuka'. Baik perlakuan warna cahaya maupun suhu air tidak berpengaruh terhadap perubahan jadwal pembukaan stomata. Hal ini mungkin disebabkan oleh tidak terdeteksinya siang dan malam bagi tanaman didalam keadaan indoor serta suhu dan kelembaban ruangan yang relatif konstan sepanjang hari, sehingga pembukaan stomata tidak membentuk pola yang tetap. Kondisi stomata yang kebanyakan membuka dapat diakibatkan oleh kelembaban relatif dalam growth chamber yang rendah yakni hanya 46,75\% sedangkan kelembaban optimum yang dibutuhkan adalah $60-75 \%$ (Rittershausen and Wilman, 2003 dalam Aditya, 2009). Sel-sel penjaga disekeliling stomata mampu mendeteksi perbedaan potensial air didalam dan diluar jaringan daun. Ketika kondisi udara kering (kelembaban rendah), stomata akan membuka untuk menjalankan transpirasi, sedangkan ketika kondisi udara lembab (udara 
mengandung uap air) maka transpirasi akan terhenti dan stomata menutup (Lange et al., 1971).

Berdasarkan analisis ANOVA dan DMRT untuk semua pengukuran kuantitatif, tidak ada perlakuan yang memberikan hasil berbeda nyata dengan perlakuan lainnya. Penyebab tidak adanya perlakuan yang berbeda nyata ini kemungkinan adalah intensitas cahaya yang diberikan terlalu rendah sehingga pertumbuhan vegetatif tidak optimal, atau cekaman dingin terlalu ringan sehingga masih bisa ditolerir oleh tanaman. Selain itu waktu pengamatan, serta ketelitian dalam pengukuran dan penghitungan juga mempengaruhi hasil penelitian ini.

\section{KESIMPULAN}

Dari penelitian ini bisa disimpulkan bahwa warna cahaya lampu LED yang berbeda berpengaruh terhadap pertambahan panjang daun dan densitas stomata. Pertambahan panjang daun terbesar dihasilkan oleh penyinaran cahaya merah, sementara densitas stomata terbesar dihasilkan oleh penyinaran cahaya biru. Warna cahaya lampu LED tidak berpengaruh terhadap jumlah daun dan pembukaan stomata. Di sisi lain, cekaman dingin melalui suhu air berpengaruh terhadap pertambahan panjang daun dan densitas stomata. Pertambahan panjang daun dan densitas stomata terbesar dihasilkan oleh suhu air biasa (suhu ruang). Cekaman dingin tidak berpengaruh terhadap jumlah daun dan pembukaan stomata.

\section{DAFTAR PUSTAKA}

[1] Aditya, E.N.R. 2009. Budidaya Tanaman Anggrek: Pengelolaan Pembibitan Anggrek Phalaenopsis di PT Ekakarya Graha Flora, Cikampek, Jawa Barat. Skrispi pada Fakultas Pertanian IPB: tidak diterbitkan

[2] Blanchard, M.G. and E.S. Runkle. 2006. Temperature during the day, but not during the night, controls flowering of Phalaenopsis orchids. Journal of Experimental Botany. 57(15) : 4043-4049

[3] Griesbach, R.J. 2002. Development of Phalaenopsis orchids for the mass-market. p. 458-465. In: J. Janick and A. Whipkey (eds.), Trends in new crops and new uses. ASHS Press, Alexandria, VA.

[4] Hatfield, J.L. and J.H. Prueger. 2015. Temperature extremes: effect on plant growth and development. Weather and Climate Extremes. 10(A): 4-10.

[5] Ichihasi, S. 1997. Orchid production and research in Japan. p. 171-212. In: Arditti, J.
And A.M. Pridgeon (eds.). Orchid biology: Reviews and perspectives, VII. Kluwer Academic Publishers, Dordrecht, The Netherlands.

[6] Kencana, I.P. 2007. Cara Cepat Membungakan Anggrek. Gramedia. Jakarta. hal. 64

[7] Landis, T.D., J.R. Pinto, R.K. Dumroese. 2013. Light Emitting Diodes (LED) Applications in Forest and Native Plant Nurseries. Forest Nursery Notes. Available at: https://www.fs.fed.us/rm/pubs_other/rmrs_20 13_landis_t001.pdf (Diakses tanggal 6 Feburari 2017)

[8] Lange, O.L., R. Losch, E.-D. Schulze, and L.Kappen. 1971. Responses of stomata to changes in humidity. Planta. 100(1): 76-86.

[9] Lüttge, U. 2001. Crassulacean Acid Metabolism. Encyclopedia of Life Sciences. Nature Publishing Group. Available at: http://rubisco.ugr.es/fisiofar/pagwebinmalcb/c ontenidos/Tema09/CAM.pdf (Diakses tanggal 1 Maret 2017).

[10] Muneer, S., E.J Kim, J.S. Park, J.H. Lee. 2014. Influence of green, red and blue light emitting diodes on multiprotein complex proteins and photosynthetic activity under different light intensities in lettuce leaves (Lactuca sativa L.). Int. J. Mol. Sci. 15: 46574670.

[11] Okamoto, K., T. Yangi., S. 1996. Development of plant growth apparatus using blue and red led as artificial light source. Acta Horticulturae. 440: 111-116

[12] Runkle, E. 2016. Red Light and Plant Growth. Michigan State University Extension Floriculture Team. Available at: http://flor.hrt.msu.edu/assets/Uploads/Redlight3.pdf (Diakses tanggal 4 Mei 2017).

[13] Runkle, E. 2015. Light Wavebands \& Their Effects on Plants. Michigan State University Extension Floriculture Team. Available at: http://flor.hrt.msu.edu/assets/Uploads/Lightwavebands.pdf (Diakses tanggal 6 Februari 2017).

[14] Winter, K. and J.A.C. Smith. 1996. Crassulacean Acid Metabolism: Biochemistry, Ecophysiology and Evolution. Springer-Verlag: Berlin. pp. 166-170 